\title{
A TUDATOS FOGYASZTÓI MAGATARTÁS DIMENZIÓI
}

Napjainkban a fogyasztói magatartás kutatásának egyik fontos területe a fogyasztók tudatosságának vizsgálata. A tudatos fogyasztó elôzetes információgyứjtést követôen eloóre megfontolt vásárlási döntéseket hoz, érvényre juttatva bizonyos, általa fontosnak tartott szempontokat. E szempontok igen változatosak lehetnek, kötődhetnek a fogyasztó önérdekeihez (ártudatosság, minőségtudatosság, márkatudatosság, egészségtudatosság stb.) vagy a köz, a társadalom érdekeinek figyelembevételéhez (környezettudatosság, társadalomtudatosság stb.). E két esetben a fogyasztókat eltéró mozgatórugók hajtják, eltéró kínálatra vágynak, és eltérốen lehet ốket megszólítani. Napjaink kutatási eredményei szerint a fogyasztók világszerte egyre inkább tudatosak, éppen ezért a vállalatok sem mehetnek el szó nélkül a témakör mellett. Hosszú távú sikerességük érdekében növekvố súlyt kell helyezniük a tudatos fogyasztókra, az ô igényeik kielégítésére. Ez többféle követelményt is támaszt velük szemben: egyrészt érdemes a jelenlegi tevékenységet és teljesítményt mindinkább a tudatos, illetve az egyre tudatosabbá váló fogyasztók igényeihez igazítani, másrészt pedig érdemes új tevékenységekbe, piaci teljesítményekbe fogni, melyek speciálisan az új, tudatos réteget célozzák meg.

Kulcsszavak: fogyasztói magatartás, tudatos fogyasztás

Felvilágosult fogyasztó, tudatos fogyasztás, fenntartható fogyasztás, etikus fogyasztás, társadalomtudatos fogyasztás, környezettudatos fogyasztás, márkatudatosság, egészségtudatosság, minőségtudatosság, ártudatosság stb. Csak úgy röpködnek ezek a fogalmak ma a médiában, de úgy túnik, hogy leginkább anélkül, hogy pontos jelentéstartalmukkal akár a fogalmak használói, akár pedig azok befogadói tisztában lennének. Ez a tanulmány azt túzte ki célul, hogy a fogalmakat és egymáshoz való viszonyukat bemutassa, és a témakörról átfogó képet nyújtson.

A téma igen fontosnak túnik. Napjaink kutatási eredményei azt mutatják, hogy a fogyasztók világszerte - és hazánkban is - egyre inkább tudatosak, bármit jelentsen is ez a fogalom. A vállalatoknak alkalmazkodniuk kell a megváltozott elvárásokhoz, ki kell elégíteniük a tudatos fogyasztók szerteágazó igényeit, legyen szó akár a kínálatról, az árakról, az információkról.

\section{A tudatos fogyasztói magatartás}

A tudatos fogyasztás elsố megközelítésben a fogyasztók elóre megfontolt, valamilyen szempontokat fokozottan érvényesítő vásárlói döntéseiben érhető tetten.
A szakirodalom nem bővelkedik a fogalmat szabatosan leíró definíciókban, inkább csak egyes részterületeinek meghatározásaival találkozhatunk. Különböző szervezetek, civil közösségek és internetes tudástárak fogalomdefinícióit tekintve az tapasztalható, hogy ezek sem egységesek abban a tekintetben, hogy milyen magatartásformák, attitüdök tartoznak a fogalom hatókörébe.

Legáltalánosabban a fogyasztói jogok tudatával és érvényesítésével, illetve az alapos információkeresố és -igénylố magatartással azonosítják a tudatos fogyasztást, erre utalnak az alábbi esetek is:

- A klasszikus fogyasztóvédelem szerint (www.tve. hu $)^{1}$ tudatos fogyasztó az, aki nem hagyja, hogy átverjék, tisztában van fogyasztói jogaival, és él is velük, tájékozódik az árakról, a termékek minőségéról, a kapcsolódó szolgáltatásokról, és a legjobb ajánlatot választja ki.

- „A fogyasztóvédelem társadalmasítása tudatos fogyasztói magatartás kialakításával" címú pályázati felhívás (TÁMOP-5.5.6/08/2) szerint (www. nfu.hu) ${ }^{2}$,a tudatos fogyasztók körültekintóbbek a vásárlásoknál, szolgáltatások igénybevételénél és képesek arra, hogy önállóan, közvetlenül is 
érvényesítsék jogaikat: a termékek kiválasztása alkalmával ismerik azokat a tájékoztató adatokat, amelyek figyelembevételével hozzák meg döntésüket. Képesek arra, hogy önállóan, közvetlenül is érvényesítsék jogaikat".

- Törőcsik (2003: p. 69.) a felvilágosult fogyasztókat trendként értelmezi, és a következót érti a fogalom alatt: „A fogyasztók/vásárlók egyre inkább tudatában vannak jogaiknak, lehetőségeiknek, így kifejezetten nehezményezik a nem korrekt tájékoztatást, a félrevezetést, botrányokat. A felvilágosult fogyasztó bizalmatlan, szkeptikus, nem mer hinni sem a gyártóknak, sem a kereskedőknek."

Vannak civil szervezetek, melyek kiterjedtebben értelmezik a tudatos fogyasztás témakörét, és a saját érdekek fokozottabb érvényesítésén túl a mások érdekeire való figyelést is számításba veszik:

- Egyfajta definícióval érhet fel az, ahogyan a Kirakat.hu és az Ipsos értelmezi Tudatos Vásárlói Indexe (TVI) részterületeit (penzcentrum.hu) fogyasztói jogok ismerete és érvényesítése, árfigyelés, vásárlás előtti tájékozódás, csak az előre eltervezett termékek megvásárlása, szerződések végigolvasása, magyar termékek iránti lojalitás, környezetbarát termékek preferálása. Az utolsó két terület értelmezhetô mások érdekeinek figyelembevételeként.

- A Tudatos Vásárlók Egyesülete (tudatosvasarlo. hu $)^{4}$ nagyobb hangsúlyt helyez mások érdekeire, az ő olvasatukban a tudatos fogyasztó nemcsak saját jogaira és érdekeire van tekintettel, figyelembe vesz etikai, társadalmi és környezeti szempontokat, tekintettel van mások (ma élő emberek, jövô nemzedékek, állatok, növények) érdekeire is.

- A Kulturális Kreatívok pedig a mások érdekeit negatívan érintő fogyasztás elutasítását helyezik fókuszba (www.kulturaliskreativok.eoldal.hu) ${ }^{5}$, és vallják, hogy a tudatos vásárlók hajlandóak és képesek függetleníteni magukat a reklámoktól, illetve képesek a reklámok mögé nézni, és igyekeznek elgondolkodni azon is, hogy mi a valódi értelme és a valódi értéke annak a terméknek. A tudatos vásárlók önkéntesen választják a „,megtehetném, de nem teszem”, a „megvehetném, de nem veszem" attitúdjét, és az ezzel a hozzáállással járó pl. egészséges előnyöket, de az esetleges társadalmi hátrányokat is.

- Szmigin és társai (2009) a tudatos fogyasztást etikus fogyasztásként értelmezik (szinonimaként használva a két terminust), fair trade és környezetbarát termékek vásárlását, valamint önkéntes egyszerúséget ${ }^{6}$ értve alatta.

A marketing, azon belül is elsősorban a fogyasztói magatartás szakirodalmában számos olyan terminus megtalálható, melyben a „tudatosság” szó jelen van, vagy más módon túnik egyértelmúnek, hogy valami módon kapcsolódik a témához:

- minőségtudatosság,

- ártudatosság,

- márkatudatosság,

- értéktudatosság,

- fogyasztói jogok tudata, felvilágosult fogyasztó,

- pénzügyi tudatosság,

- egészségtudatosság,

- tudatos táplálkozás, táplálkozástudatosság,

- országeredet-tudatosság,

- környezettudatosság,

- társadalmilag felelős fogyasztás (társadalomtudatosság),

- felelős fogyasztás,

- etikus fogyasztás,

- fenntartható fogyasztás,

- önkéntes egyszerúség koncepció stb.

Ebből a listából kiindulva, és szintetizálva a korábban ismertetett fogalommeghatározásokat, a mi olvasatunkban tudatos fogyasztó az, akire egy vagy több jellemzó igaz az alábbiak közül:

- tisztában van fogyasztói jogaival, és azokat érvényesíti is,

- tisztában van döntéseinek egyéni és/vagy társadalmi következményeivel, és tudatosan - előzetes koncepciók alapján, mélyreható informálódást és alapos megfontolást követôen - választ,

- vagy vannak felismert önös érdekei (pl. egészség, biztonság, költségtakarékosság), és azokat vásárlási döntéseiben kifejezésre is juttatja,

- és/vagy önérdekein túl hajlandó figyelembe venni etikai és (környezeti, társadalmi és gazdasági értelemben vett) fenntarthatósági szempontokat is.

\section{A tudatos fogyasztás modellje}

Ha alaposan megvizsgáljuk a fenti listát és definíciót, egy szembetúnő megállapítás adódik: ha a fogyasztók hozzáállását és motivációit nézzük, a tudatos fogyasztásnak két fő vonulatát lehet elkülöníteni egymástól: bizonyos esetekben a fogyasztók önös érdekeikre koncentrálnak, máskor pedig mások érdekeire fókuszálnak. Olyan terület is van, mely mindkét aspektust magában foglalja. 
- Az önérdekekre fókuszáló tudatosság területei: minőségtudatosság, ártudatosság, márkatudatosság, értéktudatosság, fogyasztói jogok tudata, egészségtudatosság, táplálkozástudatosság. A továbbiakban ezt a területet öntudatos fogyasztásnak nevezzük.

- A mások érdekeit szem előtt tartó tudatosság tartománya: környezettudatosság, társadalomtudatosság, etikus fogyasztás, felelős fogyasztás, fenntartható fogyasztás, önkéntes egyszerúség.

- A köztes szférába tartozik a termékekkel összefüggố országeredet-tudat, vagy tágabban értelmezve a termékeredet-tudat, és ide sorolható a pénzügyi tudatosság is. Ahogyan az késóbb olvasható, mindkét esetben lehet a magatartásnak önérdekekból, illetve mások érdekeiból fakadó motivációja is.

Az elkülönítés alapját tehát elsôsorban a fogyasztói motivációk jelentik, éppen ezért most eltekintünk azoktól az externális hatásoktól, amikor az önös érdek egyben a társadalom javára is válik, vagy megfordítva. ${ }^{7}$

Az 1. ábra összefoglalja az általunk legfontosabbnak ítélt tudatosságterületeket és fogalmakat, megjelenítve a közöttük lévő kapcsolódási pontokat.

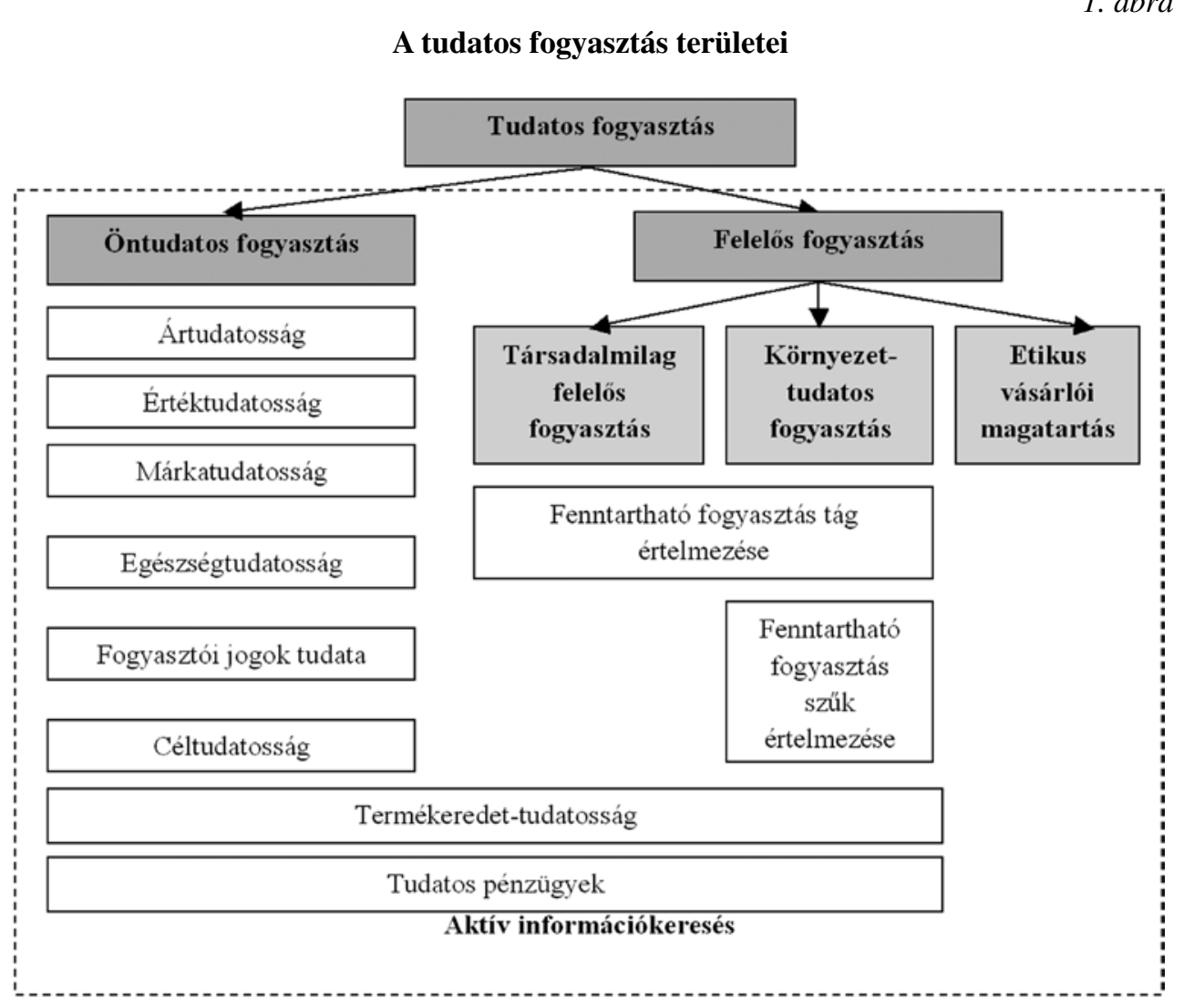

Forrás: Saját szerkesztés

Az ábrában használt fogalmak definíciója és magyarázata olvasható az alábbiakban.

\section{Egészségtudatosság}

Az egészségtudatosság ,az embernek önmagáért, épsége megórzéséért vállalt felelôssége, amely azt kívánja, hogy gondoskodjunk mi magunk jó közérzetünkról, testi-lelki és kapcsolati egyensúlyunkról” (Bagdy, 2010: p. 6.). Az Egészségügyi Stratégiai Kutatóintézet által létrehozott on-line Egészségpolitikai Fogalomtár szerint az egészségtudatos magatartás - mely az egészség megórzésének, a betegségek elkerülésének egyik fontos eszköze - nem más, mint az egyén szemlélete, viselkedése, tevékenysége annak érdekében, hogy minél tovább és minél egészségesebb maradhasson (fogalomtar.eski.hu). ${ }^{8}$ Az egészségtudatos magatartás elemei többek között az alábbiak:

- káros szenvedélyektôl való mentesség,

- egészséges, mértékletes táplálkozás,

- rendszeres testmozgás,

- lelki egészségrốl való gondoskodás,

- nyugodt élet, stresszkerülés,

- egészséges szexualitás,

- szúrővizsgálatokon való rendszeres megjelenés,

- védőoltások,

1. ábra

- táplálékkiegészítók, vitaminok fogyasztása,

- betegségek kezelése.

\section{Minóségtudatosság}

Ailawadi és társai (2001) úgy értelmezik a minőségtudatos fogyasztót, mint aki számára kiemelten fontos, hogy jó minôségú termékeket vásároljon, és a magas minőségból még árelőny esetén sem enged. Az ilyen fogyasztó számára az „elég jó” termék nem jelent megoldást (Sproles - Kendall, 1986).

A minőségtudatos fogyasztók számára tehát vásárlási döntéseikkor a minőség kiemelkedôen fontos döntési szempont, ôk nem vesznek meg megbízhatatlan eredetú és minőségú termékeket, és nem vásárolnak alacsony presztízsú kereskedelmi egységben. 


\section{Ártudatosság - értéktudatosság}

$\mathrm{Az}$ ártudatos fogyasztók vásárlásaik során kiemelt figyelmet fordítanak az árra mint döntést befolyásoló tényezóre (Ofir, 2004). Lichtenstein és társai (1993), valamint Hansen - Hen (2004) ártudatosság alatt az alacsony árak keresését és preferálását értik. Az ilyen fogyasztók nem sajnálják az idôt és energiát arra, hogy végigjárják az üzleteket, de legalábbis átlapozzák az összes akciós reklámújságot, keresvén adott termék esetében a legalacsonyabb árat. Az ártudatos fogyasztók szívesen vásárolnak diszkontban, piacon, vásárban, illetve egyéb alacsony árra pozicionált kereskedelmi egységekben. Ennek ellentéteképpen a nem ártudatos fogyasztó hajlandó többet fizetni egy adott termékért akkor, ha azt egy divatos üzletben veszi meg (Ofir, 2004).

Sproles és Kendall (1986) szélesebben értelmezik a fogalmat, szerintük az ártudatos fogyasztók nemcsak, vagy nem feltétlenül az alacsony árakat, hanem pénzükért a legnagyobb értéket keresik. Itt az árak összevetésre kerülnek a termék értéket képviseló tulajdonságaival, és a fogyasztó az ár-érték arányt összehasonlítva keresi a legjobb megoldást. Ez az értelmezés már elvezet az értéktudatosság fogalmához, melynek lényege, hogy a fogyasztók az árat és a minőséget egymással összevetve választják ki a számukra leginkább megfelelô terméket (Ailawadi és társai, 2001; Lichtenstein és társai, 1993).

\section{Márkatudatosság}

A nemzetközi és a magyar nyelvú marketing-szakirodalom alapvetően kétféle márkatudatosságot különböztet meg egymástól. Az egyik értelmezést, mely adott márka felismerésében és preferálásában ölt testet, inkább márkahúségnek nevezik. A másik értelmezés áll közelebb témánkhoz, mely szerint a márkatudatos fogyasztó vásárlási döntéseikor vonzódik a drágább, ismert márkákhoz, mivel a márkanevet és a magas árat a jobb minőség garanciájának tartja (Sproles - Kendall, 1986; Wals - Mitchell, 2010). Az ilyen fogyasztó erósen hisz abban, hogy a márkák között jelentős differenciák létezhetnek (Kim - Sung, 2009), nem szívesen vásárol kereskedelmi márkás (Walsh - Mitchell, 2010), márkanév nélküli, vagy ismeretlen nevú termékeket, inkább nem vásárol alacsony presztízsú kereskedelmi egységekben, de előszeretettel költi pénzét márkaboltokban.

\section{Fogyasztói jogok tudata}

Mint azt már korábban megfogalmaztuk, fogyasztóvédelmi szempontból tudatos fogyasztó az, aki tisztában van fogyasztói jogaival, és él is velük, tájékozódik az árakról, a termékek minőségéról, a kapcsolódó szolgáltatásokról, és a legjobb ajánlatot választja ki. 1962-ben az Egyesült Államok elnöke, John F. Kennedy javasolta a négy alapvetố fogyasztói jog - a biztonsághoz, az információhoz, a választáshoz és a képviselethez való jog - elfogadását. Azóta ez további néggyel - alapvetô szükségletek kielégítéséhez, a kárpótláshoz, oktatáshoz és az egészséges környezethez való jog - bóvült, és a nyolc alapvető jogot a Fogyasztóvédelmi Szövetségek Nemzetközi Szervezete (Consumers International) saját alapelveivé emelte. A fogyasztóvédelmi szervezetek világszerte ezekre az elvekre építik alapszabályaikat (tudatosvasarlo.hu). ${ }^{9}$ A fogyasztói jogokat minden országban törvényben is szabályozzák, Magyarországon ez az 1997. évi CLV. törvény. A jogi szabályozás célja megfelelő egyensúlyi helyzet létrehozása a piaci viszonyok két szereplóje, a fogyasztó és a gyártó/ kereskedô között annak érdekében, hogy a fogyasztó érdekei a lehetô leghatékonyabban érvényesüljenek. A fogyasztó nem rendelkezik jelentốs gazdasági erôvel, saját érdeke képviseletére, védelmére csekély mértékben képes, ezért a piacgazdaság e szereplooit fogyasztói minőségben intézményesen védeni kell a piacgazdaságnak a fogyasztóknál erősebb szereplőivel szemben (fogyasztovedelem.info). ${ }^{10}$

\section{Céltudatosság}

Jelentése a következôképpen írható körül (Dudás, 2010): Olyan vásárlói magatartás, mely nagy hangsúlyt helyez a vásárlások előre történô megtervezésére és a tervek következetes véghezvitelére. Legfóbb célja a felesleges vásárlás elkerülése, késóbb nem használt/el nem fogyasztott cikkek felhalmozásának megakadályozása, a felesleges pénzkidobástól való tartózkodás, a családi költségvetés védelme. Tipikus fogyasztói eszközei ennek a magatartásnak a heti/havi kiadások megtervezése, illetve a bevásárlólista (cédula) készítése. A céltudatos vásárló tartózkodik az impulzusvásárlásoktól, vagyis ragaszkodik a cédula tartalmához, nem jellemzőek rá a bolton belüli előre nem tervezett döntések.

\section{Felelós fogyasztás}

Az angol nyelvú szakirodalom a felelős fogyasztás fogalmát többnyire társadalom- és/vagy környezettudatos fogyasztásként értelmezi, a kifejezéseket jobbára szinonimaként használva. Özcaglar-Toulouse (2009) azonban egy nagyon jó definícióját adja a fogalomnak: szerinte olyan fogyasztással összefüggó cselekedetek tartoznak a felelős fogyasztás szférájába, melyeket a fogyasztás külvilágra gyakorolt észlelt negatív következményeinek tudata vált ki az egyénben. Három fó cselekvési stratégiát különít el egymástól, mint amelyeken keresztül az egyén kifejezheti felelősségét a külvilág felé: 
- kohézió a piaccal: Ez a stratégia megengedi az egyénnek, hogy ne korlátozza fogyasztását, éppen csak olyan termékeket vásárol, melyeknek pozitív etikai hozzáadott értéke van (pl. fair trade vagy ökotermékek). Ezt a fajta stratégiát követi a napjainkban egyre népesebb LOHAS (Lifestyle of Health and Sustainability) fogyasztói csoport (lásd például Törő́csik, 2007).

- kivonulás a piacról: A fogyasztók e stratégia értelmében kivonulnak a piac egy részéról, és tudatosan korlátozzák fogyasztásukat. Például megtermelnek maguknak dolgokat, kinyújtják tárgyaik életciklusát (javítással, használt cikkek továbbadásával/vásárlásával stb.) vagy egyszerúen csak nem vesznek meg bizonyos termékeket (pl. vegán életmód). Ilyen stratégiát követnek az önkéntes egyszerúsítók.

- a piac mozgósitása: Az igazán aktív fogyasztók másokat is igyekeznek mozgósítani, és bojkottokat (vagy éppen buycott-okat) szerveznek, petíciókat adnak be stb.

\section{Fenntartható fogyasztás}

A fenntartható fogyasztást a termékek, szolgáltatások olyan felhasználásaként értelmezhetjük, mely biztosítja az alapvetố szükségletek kielégítését, megfelelő életminôséget biztosít, de ehhez a természeti erőforrások minimális felhasználását igényli, és minimális a mérgezô, veszélyes anyagok, hulladékok, szennyezố anyagok kibocsátása (Nádudvari, 2004 nyomán). Ugyanakkor a fenntarthatatlan fogyasztás egy olyan fogyasztási modell, amely negatívan hat a környezetre, és negatívan hat ezen keresztuil magukra a fogyasztókra is: egyrészt az adott termékek és szolgáltatások konkrét fogyasztóira, másrészt pedig a tólük időben és/vagy térben távol lévố más fogyasztókra egyaránt (Burgess, 2003).

Azonban ezek a szúk értelmezések a fenntarthatóságnak csak egyik pillérét, a környezeti fenntarthatóságot érintik, és nem foglalkoznak a másik két pillérrel, a társadalmi és a gazdasági fenntarthatósággal.

- Pepper és társai (2009) már tágabban határozzák meg a fogalmat: szerintük a fenntartható fogyasztás egy széleskörúen értelmezett és vitás fogalom olyan társadalmi és környezeti aspektusokkal kapcsolatban, mint a környezetvédelem, emberi jogok, nemzedékek közötti és nemzedékeken belüli méltányosság.

- Mások a társadalmi egyenlőséget és a környezeti fenntarthatóságot foglalják bele definíciójukba: akkor fenntartható a fogyasztás, ha minden ember csak a neki járó 1,8 ha földterületet használja fel ${ }^{11}$ (Peattie - Collins, 2009).

- Park (2009) ugyan definíciószerúen nem mondja ki, de mindhárom pillért elemzi felelős befektetésekkel foglalkozó tanulmányában.

\section{Környezettudatos fogyasztás}

A környezettudatos fogyasztás „olyan vásárlást eredményez, mely legalább olyan mértékben kielégíti a szükségleteket, mint a hagyományos fogyasztói magatartás, viszont képes hozzájárulni a hulladékok csökkentéséhez, azalacsonyabb környezetterheléshez.Ezek alapján tehát nagyjából megfelel a fenntartható fogyasztás »részterületének «" (Hofmeister és társai, 2006). A fogyasztói környezettudatosság nem más, mint az ökológiai következetesség megvalósítása a vásárlási szokásokban és döntésekben, tudatában lenni annak, hogy egy termék kifejlesztése, előállítása, disztribúciója, a fogyasztás és a használat, sốt az azt követô szakasz is környezetet terhelő hatásokkal jár, és többletköltségeket okoz, törekvés a káros hatások és a többletköltségek minimalizálására (Meffert - Kirchgeorg, 1993).

A fogyasztói környezettudatosság végsố soron olyan sajátos aktivitásokban ölt testet, melyek célja a környezethasználat csökkentése (Dudás, 2006):

- környezetbarát vásárlások (biotermékek, ökotermékek, újrahasznosított alapanyagokból készüló cikkek, visszaváltható csomagolás preferálása, ingyenes bolti nejlonszatyor, eldobható termékek elutasítása),

- a környezethasználat egyéb módokon való csökkentése (például autóhasználat csökkentése, szelektív hulladékgyújtés, energiatakarékosság),

- a környezettel, a környezeti problémákkal és azok megoldásaival kapcsolatos aktív információkeresés, tájékozódás, környezetvédő tevékenység.

\section{Társadalmilag felelós fogyasztás}

A társadalomtudatosság az élet számos területén megnyilvánul, pl. adományozás, közösségi aktivitás, választási részvétel formájában (Anderson - Cunningham, 1972), de megjelenik a fogyasztásban is. A szakirodalomban fellelhetô definíciók nem egységesek annak tekintetében, hogy milyen cselekedeteket, preferenciákat sorolnak a társadalmi felelősség témakörébe, hiszen több is van, mely a környezeti szempontokat is hangsúlyozza. Ennek logikája abban rejlik, hogy a környezet állapota tagadhatatlanul hatással van a társadalom jólétére, életminőségére. Például Anderson és Cunningham (1972) szerint a tár- 
sadalomtudatos fogyasztó olyan egyén, aki nemcsak saját elégedettségét, hanem a társadalmi (és környezeti) jólétet is tekintetbe veszi vásárlási döntései során. Roberts (1995) is úgy értelmezi a társadalomtudatos fogyasztást, mint a vásárlóerô felhasználását a társadalmi érzékenység kifejezésére, és olyan termékek és szolgáltatások előnyben részesítését, melyek vélelmezhetôen pozitív (vagy legalább kevésbé negatív) hatással vannak a környezetre. Mások kihagyják a környezeti aspektusokat vizsgálódásaikból, például Mohr és társai (2001) szerint a társadalmilag felelős fogyasztó a társadalom kárára lévô cégek termékeit elutasítja, a társadalmat segító vállalatok termékeit pedig aktívan keresi.

Francois-Lecompte és Roberts (2006) nyomán a társadalmilag felelós fogyasztói magatartás elemei például a következók: a vásárlás helyének körültekintô megválasztása (etikusan múködô és/vagy helyi érdekeltségú kereskedô preferálása), méltányos kereskedelemből (fair trade) származó cikkek választása, olyan termékek preferálása, melyek árának egy része támogatási céllal hasznosul (támogató termék), hazai, illetve regionális termékek vásárlása (támogatandó a saját gazdaságot, munkahelyeket és termelóket), állatjólét figyelembevétele (állatkísérletek, rossz tartási körülmények elutasítása).

\section{Etikus fogyasztói viselkedés}

Az etikus fogyasztás egyik területe Gulyás (2008) csoportosítása szerint. Az etikus fogyasztó „tudatos szándéka, hogy fogyasztói döntéseit erkölcsi meggyőződésének és értékeinek megfelelően hozza meg”. (Gulyás, 2008: p. 107.) Az etikus fogyasztói viselkedés általában a vásárlás során jelenik meg, és olyan szituációk köthetốk ide, mint például:

- Mit tesz a vevô, ha számára kedvezôen adnak vissza rosszul a boltban? Kihasználja-e az eladó figyelmetlenségét, vagy visszaadja a pénzt?

- Felhasználja-e más üdülési csekkjét?

- Megveszi-e a CD-t, DVD-t, vagy pedig lemásolja azt?

A korábban tárgyalt társadalomtudatos fogyasztástól az különbözteti meg, hogy ebben az esetben nem az egész társadalomnak, hanem annak csak néhány szereplôjének javát szolgálja az egyén etikus viselkedése. Azon már lehet - és érdemes is - vitázni, hogy vajon ami az egyén szerint etikus, az a társadalom szerint is az-e, illetve, hogy egyáltalán a - pontosan nehezen definiálható tartalommal bíró - „etikus” szó használata indokolt-e, megfelelő-e vásárlási szituációra alkalmazva.

\section{Termékeredet-tudatosság}

A fogalom arra a fogyasztói viselkedésre utal, amikor a vásárlási döntésben befolyásoló tényezôként, döntési szempontként szerepet kap a megvásárolandó termék eredete is. A fogalom kiindulópontját a fogyasztói etnocentrizmus jelenti, mely definíció szerint a fogyasztók azon meggyőződéseit takarja, melyek hazájuk termékeinek felsőbbrendûségéról szólnak, és a belföldi termékek vásárlásának erkölcsösségére, helyességére vonatkoznak (Malota, 2003). Ez a fogalom azonban tágabban is értelmezhetô: az egyén nemcsak a saját országának, de saját régiójának, településének termékeit is preferálhatja. Az effajta tudatosság mögött többféle motiváció is meghúzódhat:

- nacionalizmus (a hazai iránti kötelességtudat, tisztelet),

- patriotizmus (a magyar nemzetgazdaság, a hazai termelók/kereskedók, a hazai munkahelyek védelme),

- környezettudatosság (minél közelebb állították elő a terméket, annál kevesebb szállítást igényel),

- minőségtudatosság (a hazai jobb minőségú),

- egészségtudatosság (a hazai egészségesebb).

Ha azért vásárol a fogyasztó magyar élelmiszert, mert azt gondolja, hogy az jobb minőségú, vagy éppen egészségesebb, akkor önérdekeit követi elsősorban. Ha azonban a vásárlás fő motivációja a magyar gazdaság, munkahelyek, gazdálkodók védelme, vagy éppen a környezet megóvása a hosszas szállításból eredố környezetszennyezéstől, akkor az a közérdek szférája.

Erre a tudatosságra épít többek között a slow food (komótos étkezés) mozgalom, a „Vegyél hazait!” kampány és Magyarországon több bolt és üzlethálózat (szociális boltok, Tanyasi Áruk Boltja, Koppány Nemzeti Boltok). De példaként hozhatók fel a különbözố eredetjelzók és származásra utaló védjegyek (Kiváló Magyar Élelmiszer védjegy, Magyar Termék Nagydíj, Magyar Termék védjegy) is.

\section{Pénzügyi tudatosság}

A pénzügyi tudatosságot egyrészt értelmezhetjük olyan pénzügyi kultúraként, melynek megléte feltételez i az általános tájékozottságot és egészséges szkepticizmust hitelfelvételi és befektetési kérdésekben, az átgondolt hitelfelvételt, az öngondoskodást, a háztartási költségvetés odafigyelő kezelését stb. Ezek a területek az egyén önérdekével vannak elsősorban kapcsolatban. Ma már Magyarországon is elérhetôk olyan banki megoldások, melyek segítségével az egyének a köz érdekeit is figyelembe tudják venni pénzügyeik intézése során. A szakirodalomban jelenlévő ,ethical bank", 
„sustainable bank” és „közösségi bank” kifejezések olyan banki tevékenységre utalnak, ahol a megtakarításaikat elhelyezô ügyfelek biztosak lehetnek abban, hogy pénzükkel a bank csak környezet- és/vagy társadalomtudatos cégeket, projekteket hitelez meg. Ilyen módon a fogyasztók adott bank vagy pénzügyi konstrukció választásával (akár egy magasabb kamatról is lemondva) kifejezetten támogathatnak pl. biotermesztôket, környezetbarát technológiával dolgozó vállalatokat, alternatív energiát előállító cégeket, munkahelyteremtő beruházásokat, helyi kis- és középvállalatokat. Ma már Magyarországon is megtehetik azt a fogyasztók, hogy befektetéseiket nemcsak az elérhetố kamatszint alapján választják ki, hanem tekintettel vannak arra is, hogy az adott alapkezelő vagy bank milyen ügyet finanszíroz az általuk megtakarított pénzzel. ${ }^{12}$

\section{Következtetések és javaslatok}

A cikk célja a tudatos fogyasztói magatartás mélyebb megismerése volt, ezt a célt egyelőre egy szakirodalmi kutatás segítségével próbáltuk megvalósítani. Ez rávilágított, hogy a fogyasztói tudatosság nem homogén kategória, számos területet takar, és e területek két markánsan elkülönülő́ csoportba sorolhatók: az önérdekeket követő és a közérdekeket szem elótt tartó cselekedetek csoportjába. A téma társadalmi és gazdasági szempontból is igen fontosnak túnik, a korábban már hivatkozott - a Kirakat.hu és az Ipsos által vizsgált Tudatos Vásárló Index (TVI), ha lassan is, de növekvő tudatosságot mutat Magyarországon. ${ }^{13}$ Ha a gazdasági aspektust nézzük, a cégeknek hosszú távú sikerességük érdekében növekvő súlyt kell helyezniük a tudatos fogyasztókra, az ô igényeik kielégítésére. Ez többféle követelményt is támaszt velük szemben:

- ki kell elégíteni a minőséggel, illetve a kedvezô ár-érték aránnyal kapcsolatos elvárásokat,

- számítani kell a fogyasztók növekvő önérdek-érvényesítésére, a fogyasztói jogok fokozódó ismeretére,

- a TVI-index eredményei szerint a magyar fogyasztók növekvố része próbálja meg tudatosan elkerülni a szokásos ,marketingtrükköket”, ellenáll a reklámoknak, előre tervez, céltudatosan vásárol, és ez alternatív marketingeszközök bevetését igényli,

- az egészség jó hívó szónak tekinthetô,

- növekvô a környezet- és társadalomtudatos fogyasztók tábora, érdemes a szokásos CSRtevékenységeken túl valódi folyamat- és termékfejlesztésbe fogni,

- a fogyasztók hitelességet és őszinteséget várnak el a vállalatoktól stb.
Érdemes tehát a jelenlegi tevékenységet és teljesítményt mindinkább a tudatos, illetve egyre tudatosabbá váló fogyasztók igényeihez igazítani. Továbbá érdemes új tevékenységekbe, piaci teljesítményekbe fogni, melyek speciálisan az új, tudatos réteget célozzák meg. Mindeközben pedig nem szabad megfeledkezni a tudatosság sokféle arcáról sem, és legalább a két fó csoport: az öntudatos és a felelős fogyasztás elkülönítéséról. E két esetben a fogyasztókat eltérő mozgatórugók hajtják, eltéró kínálatra vágynak, és eltérôen lehet ốket megszólítani. Itt ki is tudunk jelölni két további kutatási irányt:

- Milyen motivációk húzódnak meg a különböző tudatosságterületek mögött? Kvalitatív kutatási módszerekkel (mélyinterjúkkal, fókuszcsoportos vizsgálatokkal, pszichodrámával) jól vizsgálható ez a kérdéskör.

- Milyen összefüggések vannak a tudatosság egyes területei között? Ennek a kérdésnek a vizsgálata már nagymintás kutatást igényel, ahol az egyes válaszok közötti statisztikai összefüggések leírására is mód nyílik.

Mindezek alapján az 1. ábra újragondolása, pontosítása, az összefüggések és hierarchikus kapcsolatok pontosabb - esetleg többdimenziós - megjelenítése válik szükségessé.

\section{Lábjegyzet}

${ }^{1}$ http://tudatosvasarlo.hu/mi_ez, letöltve: 2010.06.30.

${ }^{2}$ http://www.nfu.hu/doc/1175, letöltve: 2010.06.30.

${ }^{3} \mathrm{http}: / /$ sajttaj.hu/index.php?page=tajekoztato\&item $=6266$, letöltve: 2010.07.02.

${ }^{4} \mathrm{http}: / /$ tudatosvasarlo.hu/mi_ez, letöltve: 2010.06.30.

${ }^{5} \mathrm{http} / / /$ www.kulturaliskreativok.eoldal.hu/oldal/tudatos-vasarloa-fogyasztoi-tarsadalomban, letöltve: 2010.06.30.

${ }^{6}$ Önkéntes egyszerúség (Voluntary Simplicity): egyének olyan törekvése, melynek értelmében önként korlátozzák fogyasztásukat. Az alapgondolat Jézustól, Buddhától, Gandhitól eredeztethető, azonban a mozgalom az 1970-es évek USA-jában egyfajta ökológiai színezetet is kapott. Az általunk vizsgált önkéntes egyszerúsítô mozgalom elsôsorban fenntarthatósági szempontok miatt vallja a következó alapelveket: kevesebb munka, kevesebb kívánság, kevesebb költés, boldogabb élet (lásd pl. Cherrier, 2007; McDonald és társai, 2006; Shaw - Moraes, 2009).

7 Például az egészségtudatos - és éppen ezért vélhetően egészséges - egyén a társadalomnak is nagyobb hasznára van, mert képes a munkavégzésre, és kevesebb egészségügyi kiadással jár, illetve a társadalom érdekeit szem előtt tartó környezettudatosság végső soron az egyén javát is szolgálja az egészségesebb táplálkozás (biotermékek), vagy éppen az egészségesebb környezet (öko-tisztítószerek, méreganyagmentes bútorok stb.) révén.

${ }^{8} \mathrm{http}: / /$ fogalomtar.eski.hu/index.php/Eg\%C3\%A9szs\% C3\%A9gtudatos_magatart\%C3\%A1s, 2010.09.09. 
${ }^{9} \mathrm{http}: / /$ tudatosvasarlo.hu/cikk/fogyaszto-nyolc-alapveto-joga, 2010.09.20.

${ }^{10} \mathrm{http} / / /$ fogyasztovedelem.info/alapfogalmak?page=3, 2010.09.20.

${ }^{11}$ Az ökológiai lábnyom elmélete szerint minden embernek 1,8 ha földterület jutna. Jelenleg a világátlag 2,2 ha, mely elég egyenlőtlenül alakul a fejlett és a fejlődő országok között, pl. az Egyesült Arab Emirátusokban 11,8 ha, az USA-ban 9,6 ha, míg Afganisztánban 0,1 ha, Szomáliában 0,4 ha, Bangladesben pedig 0,6 ha (2006-os adatok) (http://index.hu/tudomany/okolab0517/, letöltve: 2010.07.03).

${ }^{12}$ Ide tartoznak például az ún. közösségi bankok, melyek az ügyfelek megtakarításait kizárólag környezeti és/vagy társadalmi szempontból etikusan múködő vállalkozások és projektek finanszírozására használják fel. Sốt, az ügyfelek bizonyos határokon belül maguk választhatják meg, hogy mit szeretnének támogatni pénzükkel. Magyarországon egyelőre egyetlen ilyen bank múködik, a MagNet Magyar Közösségi Bank (http://tudatosvasarlo.hu/ cikk/lelkiismeretes-kapitalistak-megnyilt-elso-hazai-kozossegibank, 2010.08.17).

${ }^{13}$ A 2007 decemberében végzett első felmérés eredményei szerint a TVI 4,55 ponton állt, a 2008-as kutatás már 4,95-ös átlagot mutatott, a 2009-es TVI pedig 5,00-ös értéket kapott, amely a tudatosság enyhe növekedésére utal (http://sajttaj.hu/ index.php?page $=$ tajekoztato \&item $=6266$, letöltve: 2010.06 .30 ). Ugyanakkor a 2010-es érték csak 4,7 volt. Csökkent a magyar termékeket, a környezetbarát csomagolást valamint az egészséges és környezettudatos termékeket preferálók aránya, jelentősen nôtt ugyanakkor az interneten előre informálódó fogyasztók tábora (http://www.prherald.hu/cikk2.php?idc=20100920-154548, letöltve: 2011.02.20).

\section{Felhasznált irodalom}

Ailawadi, K.L. - Neslin, S.A. - Gedenk, K. (2001): Pursuing the Value-Conscious Consumer: Store Brands Versus National Brand Promotions. Journal of Marketing, 65, 1, p. 71-89.

Anderson, W.T.Jr. - Cunningham, W.H. (1972): The Socially Conscious Consumer. Journal of Marketing, 36, 3, p. 23-31.

Bagdy, E. (2010): Vitalitásgenerátorok, LAM (Lege Artis Medicinae), 20, 1, p. 6-7.

Burgess, J. (2003): Sustainable consumption: is it really achievable? Consumer Policy Review, 13, 3, p. 7884.

Cherrier, H. (2007): Ethical consumption practices: Coproduction of shelf-expression and social recognition. Journal of Consumer Behaviour, 6, 5, p. 321-335.

Dudás, K. (2006): A környezettudatos vásárlói magatartás elemzése. Marketing \& Menedzsment, 40. évfolyam, 2006/5-6. szám, p. 106-113.

Dudás, K. (2010): A tudatos fogyasztás, konferencia-előadás. Marketing Oktatók Klubjának 16. országos konferenciája, Budapest, 2010. augusztus 26-27. CD-ROM, p. 687-699.

Francois-Lecompte, A. - Roberts, J.A. (2006): Developing a measure of socially responsible consumption is France. Marketing Management Journal, Fall, p. 50-66.
Gulyás, E. (2008): Az etikus fogyasztás értelmezései. Szociológiai Szemle, 2008/1., p. 106-127.

Hansen, H. - L.E. Hem (2004): Brand Extension Evaluation: Effects of Affective Commitment, Involvement, Price Consciousness and Preference for Bundling in the Extension Category. Advances in Consumer Research, 31, 1, p. 375-381.

Hofmeister Tóth Á. - Simon J. - Bódi E. (2006): A fogyasztók társadalmi felelôsségének kérdései. Konferenciaelőadás, Innováció, társadalmi felelősség, fenntartható fejlődés - marketing megközelítésben, a Magyar Marketing Szövetség - Marketing Oktatók Klubjának 12. Országos Konferenciája, Budapest, 2006. augusztus 24-25.

Kim, J. - Sung, Y. (2009): Dimensions of purchase-decision involvement: Affective and cognitive involvement in product and brand. Brand Management, 16, 8, p. 504519.

Lichtenstein, D.R. - Ridgway, N.M. - Netemeyer, R.G. (1993): Price Perceptions and Consumer Shopping Behavior: A Field Study. Journal of Marketing Research, 30, 2, p. 234-245.

Malota E. (2003): Fogyasztói Etnocentrizmus - A sztereotípiák, az etnocentrizmus és az országeredet-imázs hatása a hazai és a külföldi termékek megítélésére. PhD-értekezés, http://phd.lib.uni-corvinus.hu/188/01/ malota_erzsebet.pdf (2009.10.30.)

McDonald, S. - Oates, C. J. - Young, C.W. - Hwang, K. (2006): Toward Sustainable Consumption: Researching Voluntary Simplifiers. Psychology \& Marketing, 23, 6, p. 515-534.

Meffert, H. - Kirchgeorg, M. (1993): Marktorientierts Umweltmanagement: Grundlagen und Fallstudien. Schäffer Verlag. in: Egyed Sz. (2006): Amit a magyarok a környezettudatos nevelésrôl gondolnak... Konferencia előadás, Innováció, társadalmi felelősség, fenntartható fejlődés - marketing megközelítésben, a Magyar Marketing Szövetség - Marketing Oktatók Klubjának 12. Országos Konferenciája, Budapest, 2006. augusztus 24-25.

Mohr, L.A. - Webb, D.J. - Harris, K.E. (2001): Do Consumers Expect Companies to be Socially Responsible? The Impact of Corporate Social Resposibility on Buying Behaviour. The Journal of Consumer Affairs, 35, 1, p. 45-72.

Nádudvari, Z. (2004): Fenntartható fogyasztás. Környezetvédelmi füzetek, 2004/1.

Ofir, C. (2004): Reexamining Latitude of Price Acceptability and Price Thresolds: Predicting Basic Consumer Rection to Price. Journal of Consumer Research, 30, 4, p. 612-621.

Özcaglar-Toulouse, N. (2009): What Meaning do Responsible Consumers Give to Their Consumption? An Approach by Narratives. Recherche et Applications en Marketing (English Edition), 24, 3, p. 3-22. 
Park, $J$ (2009): Sustainable consumption and the financial sector: analysing the markets for responsible investment in Hong Kong and Japan. International Journal of Consumer Studies, 33, 2, p. 206-214.

Peattie, K. - Collins, A. (2009): Guest editorial: perspectives on sustainable consumption. International Journal of Consumer Studies, 33, 2, p. 107-112.

Pepper, M. - Jackson, T. - Uzzell, D. (2009): An examination of the values that motivate socially conscious and frugal consumer behaviours. International Journal of Consumer Studises, 33, 2, p. 126-136.

Roberts, J.A. (1995): Profiling Levels of Socially Consumer Behavior: A Cluster Analytic Approach and its Implications for Marketing. Journal of Marketing Theory and Practice, 3, 4, p. 97-117.

Shaw, D. - Moraes, C. (2009): Voluntary simplicity: an exploration of market interactions. International Journal of Consumer Studies, 33, 2, p. 215-223.
Sproles, G.B. - Kendall, E.L. (1986): A Methodology for Profiling Consumers' Decision-Making Styles. The Journal of Consumer Affairs, 20, 2, p. 267-279.

Szmigin, I. - Carrigan, M. - McEachern, M.G. (2009): The conscious consumer: taking a flexible approach to ethical behaviour. International Journal of Consumer Studises, 3, 2, p. 224-231.

Törócsik M. (2003): Fogyasztói magatartás trendek. KJKKerszöv Jogi és Üzleti Kiadó Kft., Budapest

Törócsik M. (2007): A tudatos fogyasztást és az egészséget preferáló új fogyasztói trendcsoport, a LOHAS csoport megjelenése Magyarországon, Élelmiszer, Táplálkozás és Marketing, 4, 1, p. 41-47.

Walsh, G. - Mitchell, V. (2010): Consumers' intention to buy private label brands revisited. Journal of General Management, 35, 3, p. 3-24.

\section{E SZÁMUNK SZERZŐI}

Dr. Ulbert József, dékánhelyettes, habilitált egyetemi docens, Pécsi Tudományegyetem, Közgazdaságtudományi Kar; Dr. Bedô Zsolt, egyetemi adjunktus, Pécsi Tudományegyetem Közgazdaságtudományi Kar; Dr. Kovács Kármen, okleveles közgazdász, egyetemi adjunktus, Pécsi Tudományegyetem Közgazdaságtudományi Kar; Csapi Vivien, tanársegéd, Pécsi Tudományegyetem Közgazdaságtudományi Kar; Dr. Lányi Beatrix, egyetemi adjunktus, Pécsi Tudományegyetem Közgazdaságtudományi Kar; Dr. Dudás Katalin, oklevelese közgazdász, egyetemi adjunktus, Pécsi Tudományegyetem Közgazdaságtudományi Kar; Dr. Kispál-Vitai Zsuzsanna, egyetemi docens, Pécsi Tudományegyetem Közgazdaságtudományi Kar; Dr. Titkos Csaba, egyetemi docens, Pécsi Tudományegyetem Közgazdaságtudományi Kar; Deutsch Nikolett, egyetemi tanársegéd, Pécsi Tudományegyetem Közgazdaságtudományi Kar; Dr. Lóránd Balázs, PhD. egyetemi adjunktus, Pécsi Tudományegyetem Közgazdaságtudományi Kar

\section{VEZETÉSTUDOMÁNY}

